\title{
The effect of temperature on the permeation properties of Sulphonated Poly (Ether Ether) Ketone in wet flue gas streams
}

\author{
Hirra Azher, Colin Scholes, Shinji Kanehashi, Geoff Stevens, Sandra Kentish* \\ CRC for Greenhouse Gas Technologies (CO2CRC), Department of Chemical and Biomolecular \\ Engineering, The University of Melbourne, Vic 3010, Australia
}

\begin{abstract}
Membrane technology can be used to recover high purity water from power station flue gas streams. In this work, the effect of temperature on water vapour and $\mathrm{CO}_{2}$ permeation properties of Sulphonated Poly (Ether Ether) Ketone (SPEEK) with two different ion exchange capacities were investigated (1.6 meq/g and IEC $1.9 \mathrm{meq} / \mathrm{g}$ ). It was found that both permeabilities increased with increasing water activity due to increased water solubility as water concentration increased. SPEEK with IEC 1.9 meq/g exhibited higher water permeability and selectivity than IEC $1.6 \mathrm{meq} / \mathrm{g}$. At humidities greater than $50 \%$, both water vapour and $\mathrm{CO}_{2}$ permeabilities also increased as temperature increased up to $50^{\circ} \mathrm{C}$ due to the increase in diffusion of the penetrating molecules. However as temperature increased further, a significant drop in the permeability of both water and carbon dioxide occurred. This decrease was attributed to the formation of water clusters that filled the free volume in the polymer and hindered the diffusion of isolated molecules. This decrease in diffusion coupled with a reduction in solubility with increasing temperature resulted in the performance decline.
\end{abstract}

Keywords: Water; carbon dioxide; SPEEK; clustering; plasticization.

*Corresponding Author: sandraek@unimelb.edu.au 


\section{Introduction}

Brown coal fired power plants produce large amounts of flue gases containing water vapour, $\mathrm{CO}_{2}, \mathrm{~N}_{2}, \mathrm{O}_{2}$, nitric oxides $\left(\mathrm{NO}_{\mathrm{x}}\right)$, sulphur dioxides $\left(\mathrm{SO}_{2}\right)$ and fly ash. There is the potential to recover the water vapour in these flue gases using membrane technology for reuse in the process. However, for this purpose, the water recovered needs to be of sufficient purity with minimal concentrations of the acid gases, $\mathrm{CO}_{2}, \mathrm{SO}_{\mathrm{x}}$ and $\mathrm{NO}_{\mathrm{x}}$. The presence of these gases would result in an acidic water stream that would cause significant corrosion issues [1].

Sulphonated Poly (Ether Ether) Ketone (SPEEK) is a sulphonated polymer that possesses excellent proton conductivity [2-12] (Figure 1). The presence of hydrophilic $-\mathrm{SO}_{3} \mathrm{H}$ end groups increases water uptake in the polymer by increasing interactions between the water molecules and the end groups [6, 11, 13-15].

SPEEK can be synthesized via direct polymerization of sulphonated monomers or post sulphonation of Poly (Ether Ether) Ketone (PEEK) [16, 17]. PEEK is a crystalline thermoplastic that has a high chemical resistance and is only soluble in very concentrated nitric and sulphuric acids. It is this hydrophobic backbone that provides the mechanical and thermal stability of the SPEEK polymer. The addition of hydrophilic sulphonic acid end groups $\left(-\mathrm{SO}_{3} \mathrm{H}\right)$ makes SPEEK an amorphous polymer that has both hydrophilic and hydrophobic regions [16]. The degree of hydrophilicity of SPEEK is determined by the degree of sulphonation (SD) of the polymer.

It is well known that sulphonation of a polymer improves the water permeation properties $[3,4,6,16-19]$. The sulphonate groups increase the hydrophilicity of the polymer which increases both water vapour permeability and selectivity over other gases through increased interactions between polymer and water [6, 11, 13-15]. Jiang et al. [6] observed two distinct types of behaviour in a SPEEK polymer, where at low vapour activity $(<0.75)$, the water uptake was moderate but as vapour activity increased above 0.75 , there was a sharp increase in water content in the membrane. This latter increase was more pronounced in membranes of higher sulphonation degree [6]. Potreck et al. observed similar trends when analyzing the water vapour sorption kinetics in SPEEK [20]. 
Jia et al. [3] studied the effect of the sulphonation degree on the nitrogen and water vapor permeation properties of PEEK and found that the permeability of water increased with increasing sulphonation degree while the nitrogen permeability decreased. The decrease in nitrogen permeability was attributed to the reduction of free volume that arose from the presence of the $-\mathrm{SO}_{3} \mathrm{H}$ groups. Consequently, the selectivity of $\mathrm{H}_{2} \mathrm{O} / \mathrm{N}_{2}$ increased, making sulphonation an effective method for improving membrane separation performance. Similar results have been obtained by Sijbesma et al. [2] and Liu et al. [5] where water selectivity increased with increasing sulphonation degree. These authors argue that the sulphonated end groups aggregate with water molecules to form transport channels through which water diffusion readily occurs $[2,5$, $11,15,16]$.

There have been a number of studies that have looked at the effect of temperature on SPEEK permeation properties. Jia et al. [3] found that water permeability increased as temperature increased from $25-50{ }^{\circ} \mathrm{C}$ and attributed this to an increase in water diffusivity. Similar results were obtained by Wang et al. [21] who found that both water and $\mathrm{N}_{2}$ permeabilities increased with increasing temperature from $30-50{ }^{\circ} \mathrm{C}$. Most recently, Sijbesma et al. [2] considered the permeation of pure water, $\mathrm{CO}_{2}$ and $\mathrm{N}_{2}$ and mixed gases through SPEEK at $30{ }^{\circ} \mathrm{C}, 50{ }^{\circ} \mathrm{C}$ and $70{ }^{\circ} \mathrm{C}$ [2]. They found the gas permeabilities through dry membranes to be very low due to the rigid structure of SPEEK which allows no chain mobility. The presence of water vapour resulted in higher gas permeabilities. This was attributed to increased membrane swelling which resulted in increased free volume. However, these authors observed complex effects of temperature on water permeability. Permeability increased with temperature initially but decreased above $70{ }^{\circ} \mathrm{C}$. This was believed to be due to the two contrasting effects; increased diffusivity of water at high temperature due to increased swelling but reduced solubility of water in the polymer matrix [2].

However, to date, this work has focused on permeation at temperatures below $100{ }^{\circ} \mathrm{C}$ and have focused solely on $\mathrm{N}_{2}$ permeation. For the proposed application, it is necessary to consider temperatures above $100{ }^{\circ} \mathrm{C}$, as brown coal flue gas streams in Australia can reach $200^{\circ} \mathrm{C}$. It is also necessary to consider the permeation of acid gases such as carbon dioxide, to ensure that the $\mathrm{pH}$ of the product water can be evaluated. 


\section{Experimental}

\subsection{Membrane Materials}

Sulphonated Poly (Ether Ether) Ketone (SPEEK) membranes with two different ion exchange capacities (IEC) were kindly supplied by FuMA - Tech GmbH, Germany. Fumapem E630 (IEC $1.6 \mathrm{meq} / \mathrm{g}$ ) was supplied as the neat SPEEK polymer, while Fumapem E540-GF (IEC 1.9 meq/g) was supplied within glass fibre reinforcement. The membranes were received as A4 sized flat sheets on PET foils. The membranes were peeled away from the PET support and were used as supplied.

\subsection{Gas Permeation}

Pure $\mathrm{CO}_{2}$ and $\mathrm{N}_{2}$ gas permeabilities were measured on a constant volume - variable pressure (CVVP) experimental rig described in detail by Duthie et al. [22]. A variable volume - constant pressure experimental rig was also used as described by Chen et al. [23] to measure simultaneous water vapour and gas permeability for lower temperatures $\left(20-60^{\circ} \mathrm{C}\right)$ and at a range of gauge pressures (1 - $\left.10 \mathrm{bar}\right)$ [23].

A novel mixed gas permeation set-up was developed for measuring the permeability of water vapour and gas permeability at higher temperatures $\left(70-150{ }^{\circ} \mathrm{C}\right)$ and at gauge pressures of 0.5 - 5 bar described in detail in our previous work [1]. In this rig, concentration polarisation was eliminated using mechanical stirrers on both feed and permeate sides. Initial experiments determined that the minimum stirrer speed required to eliminate concentration polarization for IEC $1.9 \mathrm{meq} / \mathrm{g}$ was $500 \mathrm{rpm}$ compared to $300 \mathrm{rpm}$ for the IEC $1.6 \mathrm{meq} / \mathrm{g}$ polymer on the feed side; and $170 \mathrm{rpm}$ and $150 \mathrm{rpm}$ for both membranes on the permeate side. All subsequent experiments were thus conducted with a feed side stirrer of $600 \mathrm{rpm}$ and a permeate side stirrer speed of $200 \mathrm{rpm}$.

\subsection{Other Analyses}

A Thermogravimetric Analyser (Diamond TG/DTA, Perkin Elmer, Shelton USA) was used to measure polymer mass loss with temperature. Samples were heated over the temperature range of $50-900{ }^{\circ} \mathrm{C}$ at a rate of $10^{\circ} \mathrm{C} / \mathrm{min}$.

Membranes were dried in vacuum oven overnight before being weighed and placed in liquid water at $25-70{ }^{\circ} \mathrm{C}$ for a week. The samples were removed, blotted dry with 
tissue (Kimwipes, Kimberly Clark) to remove excess water and weighed. The water uptake (wt \%) was determined from Equation 1, where $m_{f}$ and $m_{i}$ are the final and initial mass of the sample, respectively:

$$
\text { Water Uptake }(\mathbf{w t} \%)=\frac{\mathbf{m}_{\mathbf{f}}-\mathbf{m}_{\mathbf{i}}}{\mathbf{m}_{\mathbf{i}}} \times \mathbf{1 0 0}
$$

It should be noted that the initial and final mass of the $1.9 \mathrm{meq} / \mathrm{g}$ polymer was corrected to eliminate the mass of the glass fibres before the use of Equation 1, based on the results of the TGA analysis.

The water concentration in the membrane was then determined based on a dry membrane density that varied from $1.241 \mathrm{~g} / \mathrm{cm}^{3}$ at $5^{\circ} \mathrm{C}$ to $1.237 \mathrm{~g} / \mathrm{cm}^{3}$ at $70^{\circ} \mathrm{C}$ and a water volume of $22,414 \mathrm{~cm}^{3}$ (STP) per mol. The water solubility was similarly determined by division by the saturation partial pressure of water at the measurement temperature.

The glass transition temperature $\left(\mathrm{T}_{\mathrm{g}}\right)$ of the swollen polymer was estimated from the Fox equation[24] (Equation 2), using the glass transition temperature of water as $165 \mathrm{~K}[25,26]$, that for the $1.6 \mathrm{meq} / \mathrm{g}$ SPEEK as $\sim 478 \mathrm{~K}$ and for the $1.9 \mathrm{meq} / \mathrm{g}$ SPEEK as $\sim 488 \mathrm{~K}[17]$.

$$
\frac{1}{\mathrm{~T}_{\mathrm{g}}}=\frac{\mathrm{w}_{1}}{\mathrm{~T}_{\mathrm{g} 1}}+\frac{\mathrm{w}_{2}}{\mathrm{~T}_{\mathrm{g} 2}}
$$

Where $w$ is the weight fraction of water (1) and polymer (2) respectively, while $\mathrm{T}_{\mathrm{g}}$ is the temperature in Kelvin.

\section{Results and Discussion}

\subsection{3. Thermogravimetric Analysis}

Thermogravimetric analysis of wet and dry SPEEK IEC $1.6 \mathrm{meq} / \mathrm{g}$ and IEC $1.9 \mathrm{meq} / \mathrm{g}$ is shown in Figure 2. For wet samples (dotted lines), there is an initial mass loss associated with water evaporation at $\sim 100{ }^{\circ} \mathrm{C}$ irrespective of the IEC of the SPEEK polymer. This water loss is greater for IEC $1.9 \mathrm{meq} / \mathrm{g}$ at $~ 11 \mathrm{wt} \%$ compared to $\sim 9 \mathrm{wt} \%$ observed for IEC $1.6 \mathrm{meq} / \mathrm{g}$. The second mass loss at $\sim 320-370{ }^{\circ} \mathrm{C}$ is associated with the acid-catalytic decomposition of the $-\mathrm{SO}_{3} \mathrm{H}$ group. Commonly, this mass loss is greater for a higher sulphonated polymer due to the greater presence of $-\mathrm{SO}_{3} \mathrm{H}$ groups. 
Similar TGA curves for sulphonated polymers have been observed by several researchers $[4,6,17,27-30]$.

The mass loss associated with SPEEK IEC $1.9 \mathrm{meq} / \mathrm{g}$ is less than that for the $1.6 \mathrm{meq} / \mathrm{g}$ polymer, due to this membrane being reinforced with glass fibre which remains behind and adds to the residual weight after the loss of the $\mathrm{SO}_{3} \mathrm{H}$ groups. If it is assumed that the residual polymer mass is identical for both the 1.6 and $1.9 \mathrm{meq} / \mathrm{g}$ polymers at $900^{\circ} \mathrm{C}$ it is possible to estimate that the glass fibres contribute $36 \%$ of the total mass of the 1.9 meq/g polymer.

\section{Liquid Water Uptake}

The concentration of water in the SPEEK samples after immersion in liquid water is shown in Figure 3(a). As noted in Section 2.3, the water uptake was corrected to remove the influence of the glass fibres for the $1.9 \mathrm{meq} / \mathrm{g}$ polymer. The uptake of water into SPEEK is greater for the polymer with IEC $1.9 \mathrm{meq} / \mathrm{g}$ compared to IEC $1.6 \mathrm{meq} / \mathrm{g}$, reflecting the increased density of the $-\mathrm{SO}_{3} \mathrm{H}$ groups $[6,17,18]$. The water concentration also increases as temperature increases from $5-70{ }^{\circ} \mathrm{C}$, while the solubility decreases (Figure 3(b). This reflects the increasing saturation partial pressure of water as temperature increases, which counteracts the declining solubility $[23,31$, 32]. Similar trends have been observed by Hande et al. [33] as well as Al Lafi and Hay [34]. Hande et al. obtained a water uptake of $14 \mathrm{wt} \%$ at $30^{\circ} \mathrm{C}$ and $28 \mathrm{wt} \%$ at $70^{\circ} \mathrm{C}$ for crosslinked SPEEK with IEC 2.0 meq/g (sulfonation degree 70\%) compared to 17 wt\% at $25^{\circ} \mathrm{C}$ and $24 \mathrm{wt} \%$ at $70^{\circ} \mathrm{C}$ for SPEEK IEC $1.9 \mathrm{meq} / \mathrm{g}$ obtained in this study [33]. However, these values are significantly lower than the $44 \mathrm{wt} \%$ obtained by Potreck et al. [20] at $20^{\circ} \mathrm{C}$ for SPEEK with a sulfonation degree of $59 \%$. These differences may reflect differences in the manufacture and thermal history of the membrane films.

\subsection{Water Permeability}

To enable comparison with previous studies, the water permeability for the SPEEK membranes was measured at $30{ }^{\circ} \mathrm{C}, 50{ }^{\circ} \mathrm{C}$ and $70{ }^{\circ} \mathrm{C}$ on the low temperature mixed gas permeation apparatus described by Chen et al [23] (Figure 4). As expected, the water permeability increases with increasing water activity due to the increased water 
sorption at higher water activities [6,12] which swells the membrane. For any given temperature and water activity, the water permeability is also higher for the more sulphonated membrane (IEC $1.9 \mathrm{meq} / \mathrm{g}$ ). This is a result of the increased presence of the sulphonic acid end groups that have greater interactions with water and result in higher water solubility $[2,5,16]$.

It should be noted that these results are derived when the downstream permeate humidity is zero. This implies that the swelling across the width of the membrane is uneven. Koester et al.[35] have shown that varying the humidity of the permeate stream can significantly alter the observed permeability, by varying the extent of this swelling.

The effect of temperature on water permeability gives interesting results when temperature increases from $30{ }^{\circ} \mathrm{C}$ to $50{ }^{\circ} \mathrm{C}$ (see Figure S.1 in Supplementary Information). At low water activities $(<0.4)$, the water permeability at $50{ }^{\circ} \mathrm{C}$ is lower than that at $30{ }^{\circ} \mathrm{C}$. However as water activity increases above 0.4 , the water permeability for $50{ }^{\circ} \mathrm{C}$ overtakes that for $30{ }^{\circ} \mathrm{C}$. This change in behaviour was also observed by Sijbesma et al. [2] who found a crossover point at a water activity of 0.5 for similar conditions. As shown in Figure 4, the water permeabilities for IEC $1.6 \mathrm{meq} / \mathrm{g}$ and IEC $1.9 \mathrm{meq} / \mathrm{g}$ used in this study are in good agreement with those of Sijbesma et al. [2] for SPEEK of IEC $1.7 \mathrm{meq} /$ litre. The results are also consistent with those of Liu et al. [5] who investigated water permeability through SPEEK using a cup method. They reported permeabilities at 100\% RH of $\sim 39,000$ Barrer and $\sim 110,000$ Barrer at $30{ }^{\circ} \mathrm{C}$ and $50{ }^{\circ} \mathrm{C}$, respectively, similar to the values obtained in this study.

High temperature water permeabilities measurements at $70-150{ }^{\circ} \mathrm{C}$ were conducted on the steam permeation rig described in previous work [1]. As a result, it is important confirm that the data from the two systems is comparable. This is done in Figure 5 which presents the water permeability obtained on the low temperature rig (dotted line) and the high temperature rig (solid line) at $70{ }^{\circ} \mathrm{C}$. As shown, the permeability values from the two experimental rigs match well at $70{ }^{\circ} \mathrm{C}$ for the two SPEEK IECs. The full dataset from both rigs is provided in the Supplementary Information.

The effect of temperature on water permeability at higher humidities is presented more clearly in Figure 6. There is little change in permeability as temperature increases from $30{ }^{\circ} \mathrm{C}$ to $50{ }^{\circ} \mathrm{C}$, giving a low positive activation energy of permeation, $E_{p} \sim 18 \mathrm{~kJ} / \mathrm{mol}$ and 
$15 \mathrm{~kJ} / \mathrm{mol}$ for IEC $1.6 \mathrm{meq} / \mathrm{g}$ and IEC $1.9 \mathrm{meq} / \mathrm{g}$ respectively at relative humidities above 50\%. These are compared to activation energies of water permeability obtained by various researchers as presented in Table 1 . The large variation in the $E_{p}$ values is due to the differences in the IEC values and the changing shape of the permeability curve in this region.

Table 1: Activation energy of water permeability through SPEEK at relative humidity $>50 \%$ compared to literature.

\begin{tabular}{|c|c|c|c|}
\hline & \multirow[t]{2}{*}{ Temperature $\left[{ }^{\circ} \mathrm{C}\right]$} & \multicolumn{2}{|c|}{$\mathrm{E}_{\mathrm{p}}[\mathrm{kJ} / \mathrm{mol}]$} \\
\hline & & $I E C 1.6 \mathrm{meq} / \mathrm{g}$ & $I E C 1.9 \mathrm{meq} / \mathrm{g}$ \\
\hline This Work & $30-50$ & $18 \pm 2$ & $15 \pm 5$ \\
\hline Liu et al. [5] & $30-50$ & \multicolumn{2}{|c|}{22.4} \\
\hline Jia et al. [3] & $25-50$ & \multicolumn{2}{|c|}{8.2} \\
\hline Wang et al. [21] & $25-40$ & \multicolumn{2}{|c|}{19.3} \\
\hline This Work & $50-150$ & $-41 \pm 2$ & $-50 \pm 5$ \\
\hline
\end{tabular}

Conversely, as temperature increases above $50{ }^{\circ} \mathrm{C}$, there appears to be a change in mechanism (Figure 6). Closer inspection suggests that this mechanism change occurs at $\sim 50{ }^{\circ} \mathrm{C}$ for both polymers at these higher humidities. Above these temperatures, the water permeability decreases continuously reflecting an activation energy that is negative and significantly greater in magnitude (Table 1).

The changes in activation energy of permeability may reflect changes in the activation energy for diffusivity or changes in the heat of sorption. The water solubility curve (Figure 3) gives no indication of such a shift in mechanism across this temperature range, indicating that solubility is probably not the cause of this behaviour. However, a number of workers have shown that the diffusion coefficient can undergo substantial changes in behaviour with both temperature and solute concentration[36-39]. Assuming the heat of solution for liquid water $\left(\Delta H_{s}\right)$ is similar to that at other humidities (calculated from Figure 3); the activation energy of diffusivity $\left(E_{D}\right)$ can be determined from $E_{p}$ by simple subtraction. The values are presented in Table 2. 
Table 2: Activation Energies and Heat of sorption for SPEEK at relative humidities $>50 \%$. The permeability activation energy (Ep) and heat of sorption $\left(\Delta \mathrm{H}_{\mathrm{s}}\right)$ are experimental values, while the activation energy for diffusion is calculated from the difference between these two values.

\begin{tabular}{ccccc}
\hline $\begin{array}{c}\text { Temperature } \\
{\left[{ }^{\circ} \mathrm{C}\right]}\end{array}$ & $\mathrm{E}_{\mathrm{p}}[\mathrm{kJ} / \mathrm{mol}]$ & $\begin{array}{c}\Delta \mathrm{H}_{\mathrm{s}}[\mathrm{kJ} / \mathrm{mol}] \\
\text { (from Figure 3) }\end{array}$ & $\mathrm{E}_{\mathrm{D}}[\mathrm{kJ} / \mathrm{mol}]$ \\
\hline $30-50$ & IEC $1.6 \mathrm{meq} / \mathrm{g}$ & $18 \pm 2$ & $-35.6 \pm 0.5$ & $54 \pm 3$ \\
& IEC $1.9 \mathrm{meq} / \mathrm{g}$ & $15 \pm 5$ & $-36.7 \pm 0.6$ & $52 \pm 6$ \\
\hline $50-150$ & IEC $1.6 \mathrm{meq} / \mathrm{g}$ & $-41 \pm 2$ & $-35.6 \pm 0.5$ & $-5 \pm 2$ \\
& IEC $1.9 \mathrm{meq} / \mathrm{g}$ & $-50 \pm 5$ & $-36.7 \pm 0.6$ & $-13 \pm 5$ \\
\hline
\end{tabular}

In the temperature range of $30-50^{\circ} \mathrm{C}$, the activation energy for diffusion is strongly positive. This is typical of the behavior in simple glassy systems - the diffusivity increases with temperature due to thermal expansion of the polymer, which increases free volume. However, above this temperature range, the activation energy for diffusion is negative.

Potreck et al. [20] observed an initial increase in the Fickian diffusion coefficient within two SPEEK polymers as a function of water concentration in the membrane, as well as relaxation phenomena characteristic of a glassy polymer. However, the Fickian diffusion coefficient in both sorption and desorption runs reached a plateau at a water concentration of $\sim 300 \mathrm{~cm}^{3}[\mathrm{STP}] / \mathrm{cm}^{3}$.polymer. Potreck et al. argued that these higher water vapor activities, the polymer transitioned to a rubbery state, as the water dissolved in the membrane matrix plasticized the structure and reduced the glass transition temperature $\left(T_{g}\right)$. Specifically, they argued that the SPEEK polymers transitioned from a glassy to a rubbery state when the $T_{g}$ decreased to the experimental temperature of $20{ }^{\circ} \mathrm{C}$ at a water concentration of around $600 \mathrm{~cm}^{3}[\mathrm{STP}] / \mathrm{cm}^{3}$.polymer [20]. A similar transition from a glassy to a rubbery state is also often attributed to changes in the behaviour of Nafion at high temperatures[40]. To check whether this might be the case in the present work, we estimated the glass transition temperature for the $100 \%$ humidity case using the Fox equation (Equation 2) .

The calculation in the present case (Figure 7) would suggest a transition from a glassy to a rubbery state should occur as experimental temperatures exceed $\sim 104{ }^{\circ} \mathrm{C}$ and 
$\sim 78{ }^{\circ} \mathrm{C}$ for SPEEK IEC $1.6 \mathrm{meq} / \mathrm{g}$ and IEC $1.9 \mathrm{meq} / \mathrm{g}$ respectively. These temperatures are higher than that of the permeability transitions observed in Figure 6, particularly for the $1.6 \mathrm{meq} / \mathrm{g}$ polymer. Further, a transition from a glassy to a rubbery state should lead to a more positive $E_{D}$ value, consistent with plasticization causing an increase in free volume, as observed by most workers. Vrentas[36, 41] uses free volume theory to show that the diffusivity activation energy should indeed exhibit a discontinuity at the glass transition temperature but that this should lead to a more positive $E_{D}$, rather than the negative value observed here.

Conversely, Vrentas and Duda[42] show through both theory and experiments that the diffusivity within a rubbery polymer can pass through a maximum when plotted as a function of the solute concentration. This relates to a free volume'filling' mechanism. As the free volume in the polymer fills with solute, the binary system transitions from a polymer containing individual solute molecules to a solution containing individual polymer molecules. Similar phenomena have been observed by authors considering the self diffusion of low-molecular-weight polar and nonpolar organic liquids in nanoporous inorganic materials[43-45]. These workers observe a maximum in the diffusion coefficient as the number of molecules within a nanoporous cavity increases. In the low concentration region, the effective diffusivity is determined by molecules in the vapor phase and by surface diffusivity. As the concentration increases, the effective volume of the vapor phase decreases, leading to a decrease of the effective diffusivity. Finally, capillary condensation occurs and the effective self diffusion coefficient plateaus at a value corresponding to the diffusivity of the liquid phase[43]. In the present case, it is unclear whether the diffusion maximum occurs in the glassy free volume voids, which are comparable to the inorganic cavities, or within the rubbery matrix as suggested by Vrentas and Duda[42].

The concentration dependence is consistent with the large body of other work where reductions in the diffusion coefficient occur at high water vapor activities due to the clustering of water molecules $[39,46-50]$. The phenomenon of water acting as a free volume'filling' agent to take up free volume has been directly observed by our own group when working with polyamide membranes[51]. 
De Angelis et al.[38] observe a similar transition in the diffusion coefficient for a shortside-chain perfluorosulfonic acid ionomer membrane, similar to Nafion. They observe an increasing diffusion coefficient at both $65^{\circ} \mathrm{C}$ and $120^{\circ} \mathrm{C}$ until a maximum is reached at a water concentration equivalent to $\cong 1.5 \mathrm{~mol}\left(\mathrm{H}_{2} \mathrm{O}\right) / \mathrm{mol}\left(\mathrm{SO}_{3} \mathrm{H}\right)$. Beyond this the diffusivity declined.

Given the large increases in water concentration as temperature increases in the present case (Figure 3) it is quite possible that we are observing a similar phenomenon. As temperature increases, more water is sorbed into the polymer and this causes water clusters to reduce the free volume and the corresponding diffusion coefficient.

Potreck et al. [20] reported no cluster formation in their work with SPEEK, based on the Zimm and Lundberg clustering function (Equation 3) [52].

$$
\frac{G}{V_{i}}=(1-\varphi)\left[\frac{\partial(a / \varphi)}{\partial a}\right]-1
$$

Where $a$ is the penetrant vapour activity, $\varphi$ is the penetrant volume fraction in the polymer as determined from the equilibrium sorption isotherms, $V_{i}$ is the molar volume of the penetrant $\left(\mathrm{cm}^{3} / \mathrm{mol}\right)$ and $G$ is the cluster integral. They base this conclusion upon the need for the term $G / V>0$ for clusters to form, equating to a water concentration in the membrane of at least $380 \mathrm{~cm}^{3} \mathrm{STP} / \mathrm{cm}^{3}$ polymer. Our results suggest that the water concentrations at $100 \%$ humidity in the temperature range $50-70{ }^{\circ} \mathrm{C}$ are in the range 175 to 200 for IEC $1.6 \mathrm{meq} / \mathrm{g}$ and $\sim 320-360 \mathrm{~cm}^{3} \mathrm{STP} / \mathrm{cm}^{3}$ polymer for $1.9 \mathrm{meq} / \mathrm{g}$. Again, based on these results, the formation of clusters could possibly explain the change in diffusion coefficient for the $1.9 \mathrm{meq} / \mathrm{g}$ polymer, but not the $1.6 \mathrm{meq} / \mathrm{g}$ polymer. However, the Zimm and Lundberg analysis is based on an equilibrium (rubbery) polymer[53] and hence predictions from this equation would be expected to be inaccurate for a glassy polymer. Further, Laporta et al.[54] argue that even a little water dissociates sulfonic groups within sulfonated polymers with the formation of stable sulfonic ions $\left(\mathrm{SO}_{3}{ }^{-}\right)$and that counter-ion clusters of water molecules balance the sulfonic ion charge: each cluster behaves as a nucleation centre for water molecules. This would suggest the formation of water clusters at concentrations below that predicted by the standard Zimm and Lundberg analysis. 


\section{5. $\mathrm{CO}_{2}$ and $\mathrm{N}_{2}$ Permeability}

The permeabilities for pure dry $\mathrm{CO}_{2}$ and $\mathrm{N}_{2}$ feed streams are higher for the more sulphonated SPEEK membrane (IEC $1.9 \mathrm{meq} / \mathrm{g}$ ) at all temperatures, reflecting the greater fractional free volume created by the additional sulphonic groups. The permeability values obtained by Sijbesma et al. [2] at $30^{\circ} \mathrm{C}$ are lower than we obtain (Table 1), while their selectivity is higher. This is indicative of a lower fractional free volume in their polymer, which again may reflect differences in the manufacture and thermal history of the membrane films..

The dry permeability of both $\mathrm{CO}_{2}$ and $\mathrm{N}_{2}$ increases with increasing temperature due to an increase in diffusivity (Tables 3 and 4 and Figure 8). The increase is greater for $\mathrm{N}_{2}$ and this consequently results in a reduction in $\mathrm{CO}_{2} / \mathrm{N}_{2}$ selectivity as temperature increases.

Table 3: Pure $\mathrm{CO}_{2}$ and $\mathrm{N}_{2}$ permeability in a dry system through SPEEK IEC $1.6 \mathrm{meq} / \mathrm{g}$ and IEC 1.9 meq/g compared to literature.

\begin{tabular}{cccc}
\hline & \multicolumn{2}{c}{ This Work } & Sijbesma et al. [2] \\
& \multicolumn{2}{c}{$\mathrm{T}=30^{\circ} \mathrm{C}$} & $\mathrm{T}=30^{\circ} \mathrm{C}$ \\
\hline IEC (Meq/g) & 1.6 & 1.9 & 1.7 \\
\hline $\begin{array}{c}\mathrm{CO}_{2} \text { Permeability } \\
\text { [Barrer] }\end{array}$ & $0.42 \pm 0.03$ & $0.80 \pm 0.02$ & $0.11 \pm 0.01$ \\
$N_{2}$ Permeability \\
$\begin{array}{c}\text { [Barrer] } \\
\mathrm{CO}_{2} / \mathrm{N}_{2}\end{array}$
\end{tabular}

Table 4: Activation Energies of Permeation for $\mathrm{CO}_{2}$ and $\mathrm{N}_{2}$ through SPEEK in dry conditions

\begin{tabular}{ccc}
\hline \multirow{2}{*}{$\begin{array}{c}\text { Activation } \\
\text { Energies, } \mathrm{E}_{\mathrm{p}}\end{array}$} & \multicolumn{2}{c}{ This Work } \\
\cline { 2 - 3 } & IEC 1.6 & IEC 1.9 \\
$\mathrm{meq} / \mathrm{g}$ & $\mathrm{meq} / \mathrm{g}$ \\
\hline $\mathrm{CO}_{2}[\mathrm{~kJ} / \mathrm{mol}]$ & $19 \pm 2$ & $14.8 \pm 0.7$ \\
$\mathrm{~N}_{2}[\mathrm{~kJ} / \mathrm{mol}]$ & $26.6 \pm 0.5$ & $24.4 \pm 0.6$ \\
\hline
\end{tabular}


The dry $\mathrm{CO}_{2}$ permeabilities are considerably lower when compared to permeabilities in the presence of water (Figure 8). This behaviour is reported by various researchers and is due to the plasticization of the membrane in the presence of water [2-4]. The activation energy of $\mathrm{CO}_{2}$ permeability at low temperatures $\left(30-50{ }^{\circ} \mathrm{C}\right)$ in humid conditions is similar to that for the same temperature range in dry conditions i.e. $E_{p} \sim$ $10 \mathrm{~kJ} / \mathrm{mol}$ in wet conditions compared to $E_{p} \sim 17 \mathrm{~kJ} / \mathrm{mol}$ in dry conditions. This suggests the mechanisms for permeation are comparable at low temperatures, reflecting the low concentration of water in the membrane. Furthermore, the $\mathrm{CO}_{2}$ permeability increases as feed water activity increases due to the increased interactions between the $-\mathrm{SO}_{3} \mathrm{H}$ groups and water molecules that swell the membrane and open pathways for $\mathrm{CO}_{2}$ diffusion. $\mathrm{CO}_{2}$ permeability is greater for IEC $1.9 \mathrm{meq} / \mathrm{g}$ compared to IEC $1.6 \mathrm{meq} / \mathrm{g}$, reflecting the greater swelling of the more sulphonated membrane.

Importantly, similar behaviour to the water permeability in Figure 6 is observed with respect to temperature. That is, the $\mathrm{CO}_{2}$ permeability increases from $30{ }^{\circ} \mathrm{C}$ to $50{ }^{\circ} \mathrm{C}$ but decreases as temperature increases above $50^{\circ} \mathrm{C}$. Similar behaviour was observed by $\mathrm{Ma}$ and Skou for the $\mathrm{CO}_{2}$ permeability in a hydrated Nafion membrane [55]. This again may reflect a change in the water clustering or free volume filling within the membrane discussed in the previous section. A decline in $\mathrm{CO}_{2}$ diffusivity with increasing water content in the membrane has been observed by other workers $[23,56]$ and can again be related to increases in the number and size of water clusters, which inhibit the flow of other gases. This is often referred to as 'anti-plasticisation'.

$\mathrm{N}_{2}$ permeability was also measured for the two SPEEK membranes under humid conditions. The results obtained were similar in magnitude to those obtained by Sijbesma et al. [2] $<1$ Barrer); however such a low $\mathrm{N}_{2}$ permeability is too close to the detection limit of the gas chromatography unit used in mixed gas measurements for accurate values to be reported here.

The selectivity of $\mathrm{H}_{2} \mathrm{O} / \mathrm{CO}_{2}$ for the two IEC membranes is presented in Figure 9. As shown, the selectivity is relatively constant up to $50{ }^{\circ} \mathrm{C}$ below which it decreases. This is a direct result of the anomaly in the water permeability behaviour observed in Figure 6. Sijbesma et al. [2] found that the selectivity of $\mathrm{H}_{2} \mathrm{O} / \mathrm{N}_{2}$ decreased with temperature as in this case but in fact increased with increasing feed water activity. This is because the 
increase in $\mathrm{CO}_{2}$ permeation with increasing feed water activity is considerable compared to the limited changes in $\mathrm{N}_{2}$ permeability observed in their work. As stated by many other researchers, a higher degree of sulphonation does improve the separation performance of the membranes as shown by the higher selectivity for IEC 1.9 meq/g (dotted line) compared to IEC $1.6 \mathrm{meq} / \mathrm{g}$ (solid line) at any given water activity and temperature $[3,4,16,17]$. The higher selectivity in the present case may also reflect the presence of the glass fibre reinforcement in the IEC $1.9 \mathrm{meq} / \mathrm{g}$ polymer, which will restrict polymer swelling.

\section{Conclusion}

The effect of sulphonation degree and temperature on the permeation properties of Sulphonated Poly (Ether Ether) Ketone was studied. The concentration of water in the polymer increased with increasing temperature, reflecting the higher partial pressure of water in the vapour phase and was higher for the highly sulphonated membrane with an IEC $1.9 \mathrm{meq} / \mathrm{g}$. A change in mechanism for both water and $\mathrm{CO}_{2}$ permeability was observed at $\sim 50{ }^{\circ} \mathrm{C}$ for both membranes at humidities greater than $50 \%$. Below this transition temperature, both water vapour and $\mathrm{CO}_{2}$ permeabilities increased with temperature, reflecting the common increases in diffusivity that occur as the polymer expands. However, above $70{ }^{\circ} \mathrm{C}$ all permeabilities declined with temperature. This is probably due to the large water concentrations hindering the diffusion of both water and $\mathrm{CO}_{2}$ as this solute occupies the free volume.

The SPEEK membrane with IEC $1.9 \mathrm{meq} / \mathrm{g}$ had better water permeation properties and $\mathrm{H}_{2} \mathrm{O} / \mathrm{CO}_{2}$ selectivity compared to IEC $1.6 \mathrm{meq} / \mathrm{g}$. This was due to the higher sulphonic acid content of the membrane that improved membrane performance. This means that this membrane shows greater potential for use to recover water from wet flue gas streams.

\section{Acknowledgements}

The authors acknowledge funding provided by Brown Coal Innovation Australia (BCIA) and the Australian Government through its CRC program to support this research project. SK acknowledges the support of the Australian Research Council through the 
Discovery Project DP150100977. The authors also acknowledge the kind donation of the Fumapem E - 630 and Fumapem E -540 - GF membrane samples by Fuma-Tech GMBH.

\section{References}

[1] H. Azher, C.A. Scholes, G.W. Stevens, S.E. Kentish, Water permeation and sorption properties of Nafion 115 at elevated temperatures, Journal of Membrane Science, 459 (2014) 104-113.

[2] H. Sijbesma, K. Nymeijer, R. van Marwijk, R. Heijboer, J. Potreck, M. Wessling, Flue gas dehydration using polymer membranes, Journal of Membrane Science, 313 (2008) 263-276.

[3] L. Jia, X. Xu, H. Zhang, J. Xu, Sulfonation of polyetheretherketone and its effects on permeation behavior to nitrogen and water vapor, Journal of Applied Polymer Science, 60 (1996) 1231-1237.

[4] L. Jia, X. Xu, H. Zhang, J. Xu, Permeation of nitrogen and water vapor through sulfonated polyetherethersulfone membrane, Journal of Polymer Science Part B: Polymer Physics, 35 (1997) 2133-2140.

[5] S. Liu, F. Wang, T. Chen, Synthesis of Poly(ether ether ketone)s with High Content of Sodium Sulfonate Groups as Gas Dehumidification Membrane Materials, Macromolecular Rapid Communications, 22 (2001) 579-582.

[6] R. Jiang, H.R. Kunz, J.M. Fenton, Investigation of membrane property and fuel cell behavior with sulfonated poly(ether ether ketone) electrolyte: Temperature and relative humidity effects, Journal of Power Sources, 150 (2005) 120-128.

[7] P. Xing, G.P. Robertson, M.D. Guiver, S.D. Mikhailenko, K. Wang, S. Kaliaguine, Synthesis and characterization of sulfonated poly(ether ether ketone) for proton exchange membranes, Journal of Membrane Science, 229 (2004) 95-106.

[8] F. Wang, J. Li, T. Chen, J. Xu, Synthesis of poly(ether ether ketone) with high content of sodium sulfonate groups and its membrane characteristics, Polymer, 40 (1999) 795799.

[9] L. Li, J. Zhang, Y. Wang, Sulfonated poly(ether ether ketone) membranes for direct methanol fuel cell, Journal of Membrane Science, 226 (2003) 159-167.

[10] C. Manea, M. Mulder, Characterization of polymer blends of polyethersulfone/sulfonated polysulfone and polyethersulfone/sulfonated polyetheretherketone for direct methanol fuel cell applications, Journal of Membrane Science, 206 (2002) 443-453.

[11] M. Gil, X. Ji, X. Li, H. Na, J. Eric Hampsey, Y. Lu, Direct synthesis of sulfonated aromatic poly(ether ether ketone) proton exchange membranes for fuel cell applications, Journal of Membrane Science, 234 (2004) 75-81.

[12] E. Drioli, A. Regina, M. Casciola, A. Oliveti, F. Trotta, T. Massari, Sulfonated PEEK-WC membranes for possible fuel cell applications, Journal of Membrane Science, 228 (2004) 139-148.

[13] F.G. Wilhelm, I.G.M. Pünt, N.F.A. van der Vegt, H. Strathmann, M. Wessling, Cation permeable membranes from blends of sulfonated poly(ether ether ketone) and poly(ether sulfone), Journal of Membrane Science, 199 (2002) 167-176. 
[14] M. Arigonda, A.P. Deshpande, S. Varughese, Effect of PES on the morphology and properties of proton conducting blends with sulfonated poly(ether ether ketone), Journal of Applied Polymer Science, 127 (2013) 5100-5110.

[15] R.Y.M. Huang, P. Shao, X. Feng, C.M. Burns, Pervaporation separation of water/isopropanol mixture using sulfonated poly(ether ether ketone) (SPEEK) membranes: transport mechanism and separation performance, Journal of Membrane Science, 192 (2001) 115-127.

[16] A.L. Khan, X. Li, I.F.J. Vankelecom, Mixed-gas $\mathrm{CO}_{2} / \mathrm{CH}_{4}$ and $\mathrm{CO}_{2} / \mathrm{N}_{2}$ separation with sulfonated PEEK membranes, Journal of Membrane Science, 372 (2011) 87-96.

[17] S.M.J. Zaidi, S.D. Mikhailenko, G.P. Robertson, M.D. Guiver, S. Kaliaguine, Proton conducting composite membranes from polyether ether ketone and heteropolyacids for fuel cell applications, Journal of Membrane Science, 173 (2000) 17-34.

[18] Y. Li, T.S. Chung, Highly selective sulfonated polyethersulfone (SPES)-based membranes with transition metal counterions for hydrogen recovery and natural gas separation, Journal of Membrane Science, 308 (2008) 128-135.

[19] W.-J. Chen, C.R. Martin, Gas-transport properties of sulfonated polystyrenes, Journal of Membrane Science, 95 (1994) 51-61.

[20] J. Potreck, F. Uyar, H. Sijbesma, K. Nijmeijer, D. Stamatialis, M. Wessling, Sorption induced relaxations during water diffusion in S-PEEK, Physical Chemistry Chemical Physics, 11 (2009) 298-308.

[21] F. Wang, T. Chen, J. Xu, Synthesis of poly(ether ether ketone) containing sodium sulfonate groups as gas dehumidification membrane material, Macromolecular Rapid Communications, 19 (1998) 135-137.

[22] X. Duthie, S. Kentish, C. Powell, K. Nagai, G. Qiao, G. Stevens, Operating temperature effects on the plasticization of polyimide gas separation membranes, Journal of Membrane Science, 294 (2007) 40-49.

[23] G.Q. Chen, C.A. Scholes, G.G. Qiao, S.E. Kentish, Water vapor permeation in polyimide membranes, Journal of Membrane Science, 379 (2011) 479-487.

[24] T.G. Fox, Influence of diluent and of copolymer composition on the glass temperature of a polymer system, Bulletin of the American Physics Society, 2 (1956) 123-.

[25] N. Giovambattista, C.A. Angell, F. Sciortino, H.E. Stanley, Glass-Transition Temperature of Water: A Simulation Study, Physical Review Letters, 93 (2004) 047801.

[26] T. Reinot, N.C. Dang, R. Jankowiak, Hyperquenched Glassy Water and Hyperquenched Glassy Ethanol Probed by Single Molecule Spectroscopy, The Journal of Physical Chemistry B, 113 (2009) 4303-4313.

[27] P. Knauth, H. Hou, E. Bloch, E. Sgreccia, M.L. Di Vona, Thermogravimetric analysis of SPEEK membranes: Thermal stability, degree of sulfonation and cross-linking reaction, Journal of Analytical and Applied Pyrolysis, 92 (2011) 361-365.

[28] M.L. Di Vona, G. Alberti, E. Sgreccia, M. Casciola, P. Knauth, High performance sulfonated aromatic ionomers by solvothermal macromolecular synthesis, International Journal of Hydrogen Energy, 37 (2012) 8672-8680.

[29] M.L. Di Vona, E. Sgreccia, S. Licoccia, G. Alberti, L. Tortet, P. Knauth, Analysis of Temperature-Promoted and Solvent-Assisted Cross-Linking in Sulfonated Poly(ether ether ketone) (SPEEK) Proton-Conducting Membranes, The Journal of Physical Chemistry B, 113 (2009) 7505-7512.

[30] R.T.S. Muthu Lakshmi, V. Choudhary, I.K. Varma, Sulphonated poly(ether ether ketone): Synthesis and characterisation, Journal of Materials Science, 40 (2005) 629636. 
[31] N.H. Jalani, R. Datta, The effect of equivalent weight, temperature, cationic forms, sorbates, and nanoinorganic additives on the sorption behavior of Nafion $®$, Journal of Membrane Science, 264 (2005) 167-175.

[32] J. Lee, C.M. Doherty, A.J. Hill, S.E. Kentish, Water vapor sorption and free volume in the aromatic polyamide layer of reverse osmosis membranes, Journal of Membrane Science, 425-426 (2013) 217-226.

[33] V.R. Hande, S.K. Rath, S. Rao, M. Patri, Cross-linked sulfonated poly (ether ether ketone) (SPEEK)/reactive organoclay nanocomposite proton exchange membranes (PEM), Journal of Membrane Science, 372 (2011) 40-48.

[34] A.G. Al Lafi, J.N. Hay, State of the water in crosslinked sulfonated poly(ether ether ketone), Journal of Applied Polymer Science, 128 (2013) 3000-3009.

[35] S. Koester, F. Roghmans, M. Wessling, Water vapor permeance: The interplay of feed and permeate activity, Journal of Membrane Science, 485 (2015) 69-78.

[36] J.S. Vrentas, C.M. Vrentas, Solvent Self-Diffusion in Glassy Polymer-Solvent Systems, Macromolecules, 27 (1994) 5570-5576.

[37] S. Sato, M. Suzuki, S. Kanehashi, K. Nagai, Permeability, diffusivity, and solubility of benzene vapor and water vapor in high free volume silicon- or fluorine-containing polymer membranes, Journal of Membrane Science, 360 (2010) 352-362.

[38] M.G. De Angelis, S. Lodge, M. Giacinti Baschetti, G.C. Sarti, F. Doghieri, A. Sanguineti, P. Fossati, Water sorption and diffusion in a short-side-chain perfluorosulfonic acid ionomer membrane for PEMFCS: effect of temperature and pre-treatment, Desalination, 193 (2006) 398-404.

[39] M.-J. Chang, A.S. Myerson, T.K. Kwei, The effect of hydrogen bonding on vapor diffusion in water-soluble polymers, Journal of Applied Polymer Science, 66 (1997) 279291.

[40] J. Li, M. Pan, H. Tang, Understanding short-side-chain perfluorinated sulfonic acid and its application for high temperature polymer electrolyte membrane fuel cells, RSC Advances, 4 (2014) 3944-3965.

[41] J.S. Vrentas, A Free-Volume Interpretation of the Influence of the Glass Transition on Diffusion in Amorphous Polymers, Journal of Applied Polymer Science, 22 (1978) 2325-2339.

[42] J.S. Vrentas, J.L. Duda, Diffusion in Polymer-Solvent Systems. 11. A Predictive Theory for the Dependence of Diffusion Coefficients on Temperature, Concentration, and Molecular Weight, Journal of Polymer Science Part B: Polymer Physics, 15 (1977) 417-439.

[43] R. Valiullin, P. Kortunov, J. Kärger, V. Timoshenko, Concentration-dependent selfdiffusion of liquids in nanopores: A nuclear magnetic resonance study, The Journal of Chemical Physics, 120 (2004) 11804-11814.

[44] M.R. Bonilla, R. Valiullin, J. Kärger, S.K. Bhatia, Understanding Adsorption and Transport of Light Gases in Hierarchical Materials Using Molecular Simulation and Effective Medium Theory, The Journal of Physical Chemistry C, 118 (2014) 1435514370.

[45] E. Beerdsen, D. Dubbeldam, B. Smit, Loading Dependence of the Diffusion Coefficient of Methane in Nanoporous Materials, The Journal of Physical Chemistry B, 110 (2006) 22754-22772.

[46] G.Q. Chen, C.A. Scholes, C.M. Doherty, A.J. Hill, G.G. Qiao, S.E. Kentish, Modeling of the sorption and transport properties of water vapor in polyimide membranes, Journal of Membrane Science, 409-410 (2012) 96-104. 
[47] V. Detallante, D. Langevin, C. Chappey, M. Métayer, R. Mercier, M. Pinéri, Kinetics of water vapor sorption in sulfonated polyimide membranes, Desalination, 148 (2002) 333-339.

[48] E. Favre, P. Schaetzel, Q.T. Nguygen, R. Clément, J. Néel, Sorption, diffusion and vapor permeation of various penetrants through dense poly(dimethylsiloxane) membranes: a transport analysis, Journal of Membrane Science, 92 (1994) 169-184.

[49] W.P. Hsu, R.J. Li, A.S. Myerson, T.K. Kwei, Sorption and diffusion of water vapour in hydrogen-bonded polymer blends, Polymer, 34 (1993) 597-603.

[50] S.J. Metz, W.J.C. Van De Ven, M.H.V. Mulder, M. Wessling, Mixed gas water vapor/N2 transport in poly(ethylene oxide) poly(butylene terephthalate) block copolymers, Journal of Membrane Science, 266 (2005) 51-61.

[51] J. Lee, C.M. Doherty, A.J. Hill, S.E. Kentish, Water vapor sorption and free volume in the aromatic polyamide layer of reverse osmosis membranes, Journal of Membrane Science, 425-426 (2013) 217-226.

[52] B.H. Zimm, J.L. Lundberg, Sorption of Vapors by High Polymers, The Journal of Physical Chemistry, 60 (1956) 425-428.

[53] E.M. Davis, Y.A. Elabd, Water Clustering in Glassy Polymers, The Journal of Physical Chemistry B, 117 (2013) 10629-10640.

[54] M. Laporta, M. Pegoraro, L. Zanderighi, Perfluorosulfonated membrane (Nafion): FT-IR study of the state of water with increasing humidity, Physical Chemistry Chemical Physics, 1 (1999) 4619-4628.

[55] S. Ma, E. Skou, CO2 permeability in Nafion ${ }^{\circledR}$ EW1100 at elevated temperature, Solid State Ionics, 178 (2007) 615-619.

[56] S. Kanehashi, T. Nakagawa, K. Nagai, X. Duthie, S. Kentish, G. Stevens, Effects of carbon dioxide-induced plasticization on the gas transport properties of glassy polyimide membranes, Journal of Membrane Science, 298 (2007) 147-155. 


\section{Figure Captions:}

Figure 1: Structure of Sulphonated Poly (Ether Ether) Ketone.

Figure 2: Thermogravimetric Analysis (TGA) of wet (dotted line) and dry (solid line) SPEEK with IEC $1.6 \mathrm{meq} / \mathrm{g}$ and IEC $1.9 \mathrm{meq} / \mathrm{g}$.

Figure 3: Water concentration (a) and water solubility (b) in SPEEK with IEC $1.6 \mathrm{meq} / \mathrm{g}$ and IEC $1.9 \mathrm{meq} / \mathrm{g}$ as a function of temperature. Note that the volume of the glass fibres has been subtracted from the total polymer volume for the $1.9 \mathrm{meq} / \mathrm{g}$ case.

Figure 4: Water permeability as a function of feed water activity at $30{ }^{\circ} \mathrm{C}(\mathrm{a}), 50{ }^{\circ} \mathrm{C}(\mathrm{b})$ and $70{ }^{\circ} \mathrm{C}$ (c) for SPEEK with IEC $1.9 \mathrm{meq} / \mathrm{g}$ (dotted line) and IEC $1.6 \mathrm{meq} / \mathrm{g}$ (solid line) compared with that obtained by Sijbesma et al, 2008 for a membrane of $1.7 \mathrm{meq} / \mathrm{g}$ (open data points) [2]. Note that the $1.9 \mathrm{meq} / \mathrm{g}$ data has not been corrected to account for the glass fibres.

Figure 5: Water permeability for SPEEK with IEC $1.9 \mathrm{meq} / \mathrm{g}$ and IEC $1.6 \mathrm{meq} / \mathrm{g}$ at $70{ }^{\circ} \mathrm{C}$ obtained on the steam experimental rig (solid lines) and mixed gas permeation rig described by Chen et al. [23] (dotted lines). Note that the $1.9 \mathrm{meq} / \mathrm{g}$ data has not been corrected to account for the glass fibres.

Figure 6: Water permeability through SPEEK with IEC $1.6 \mathrm{meq} / \mathrm{g}$ (solid lines) and IEC $1.9 \mathrm{meq} / \mathrm{g}$ (dotted lines) as a function of temperature and feed RH (\%). Note that the $1.9 \mathrm{meq} / \mathrm{g}$ data has not been corrected to account for the glass fibres. The data for $30^{\circ} \mathrm{C}$ and $50^{\circ} \mathrm{C}$ is interpolated from data obtained on the mixed gas rig, while the data for $70^{\circ} \mathrm{C}$ and above is from the steam rig.

Figure 7: The theoretical $T_{g}$ for SPEEK IEC $1.6 \mathrm{meq} / \mathrm{g}$ and SPEEK IEC $1.9 \mathrm{meq} / \mathrm{g}$ as a function of experimental temperature, based on Equation 2. The dashed line represents the point where the glass transition temperature is equal to the experimental temperature.

Figure 8: $\mathrm{CO}_{2}$ permeability as a function of temperature for the IEC $1.6 \mathrm{meq} / \mathrm{g}$ (solid line) and IEC $1.9 \mathrm{meq} / \mathrm{g}$ (dotted line) polymer at different RH \%.

Figure 9: Selectivity of $\mathrm{H}_{2} \mathrm{O} / \mathrm{CO}_{2}$ as a function of feed $\mathrm{RH}(\%)$ and temperature for IEC $1.6 \mathrm{meq} / \mathrm{g}$ (solid line) and IEC $1.9 \mathrm{meq} / \mathrm{g}$ (dotted line). 


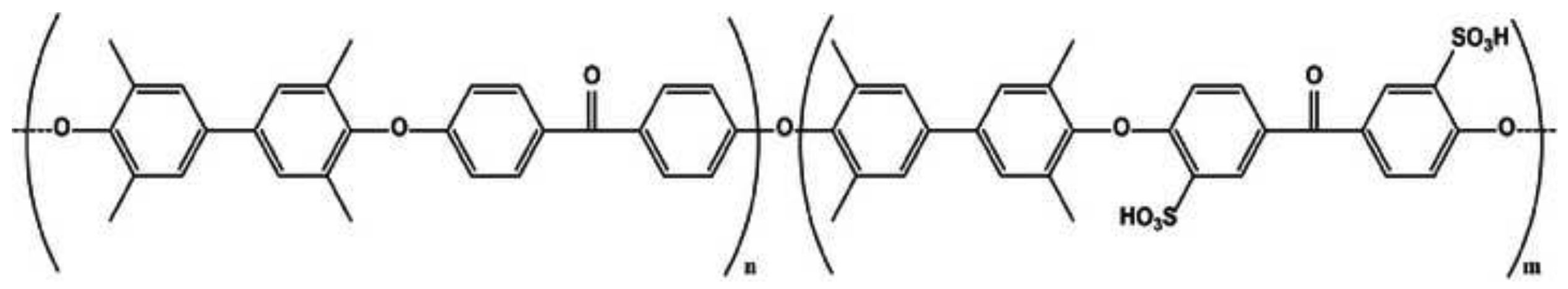


Figure 2

Click here to download high resolution image

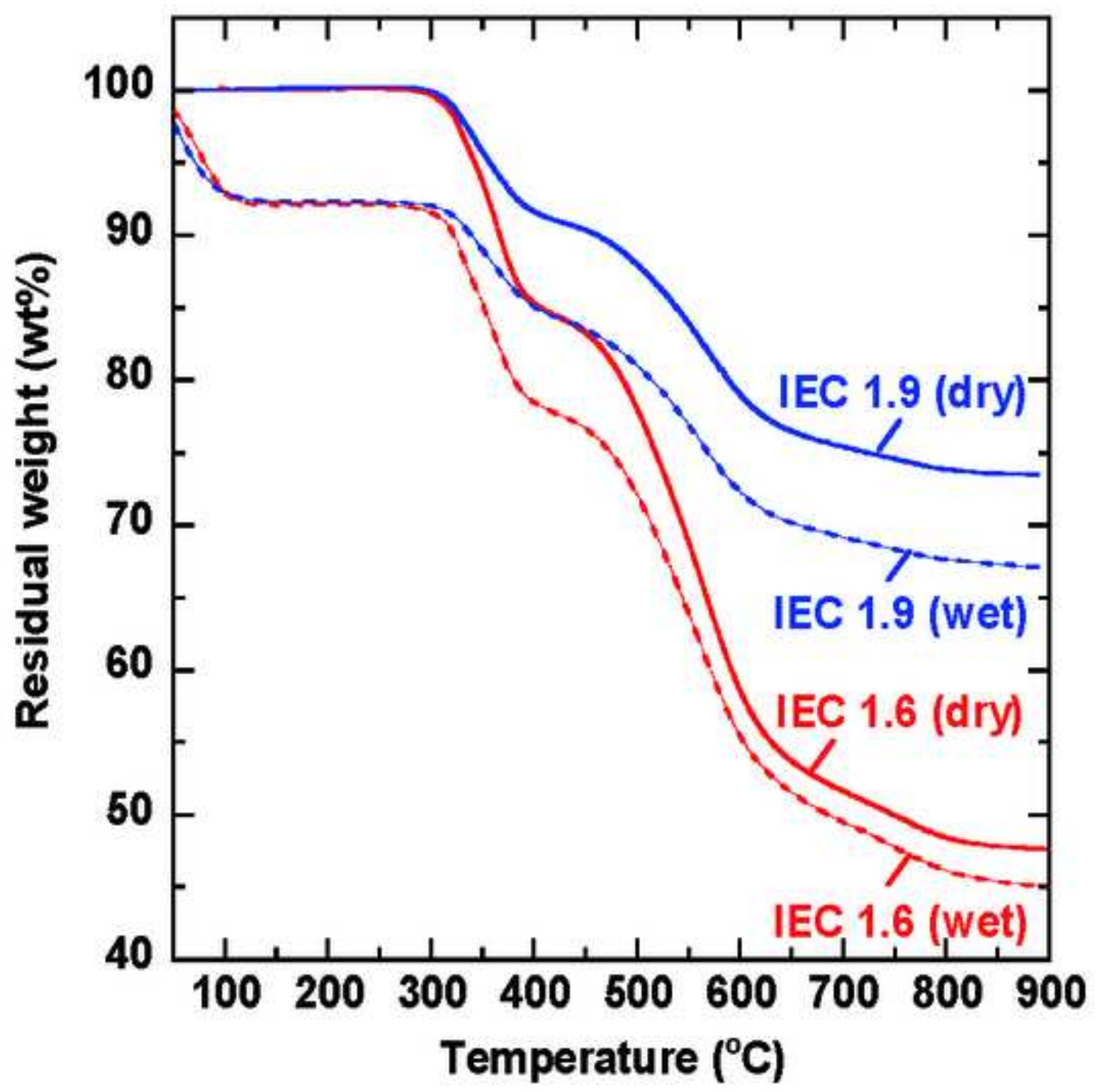


Figure 3

Click here to download high resolution image
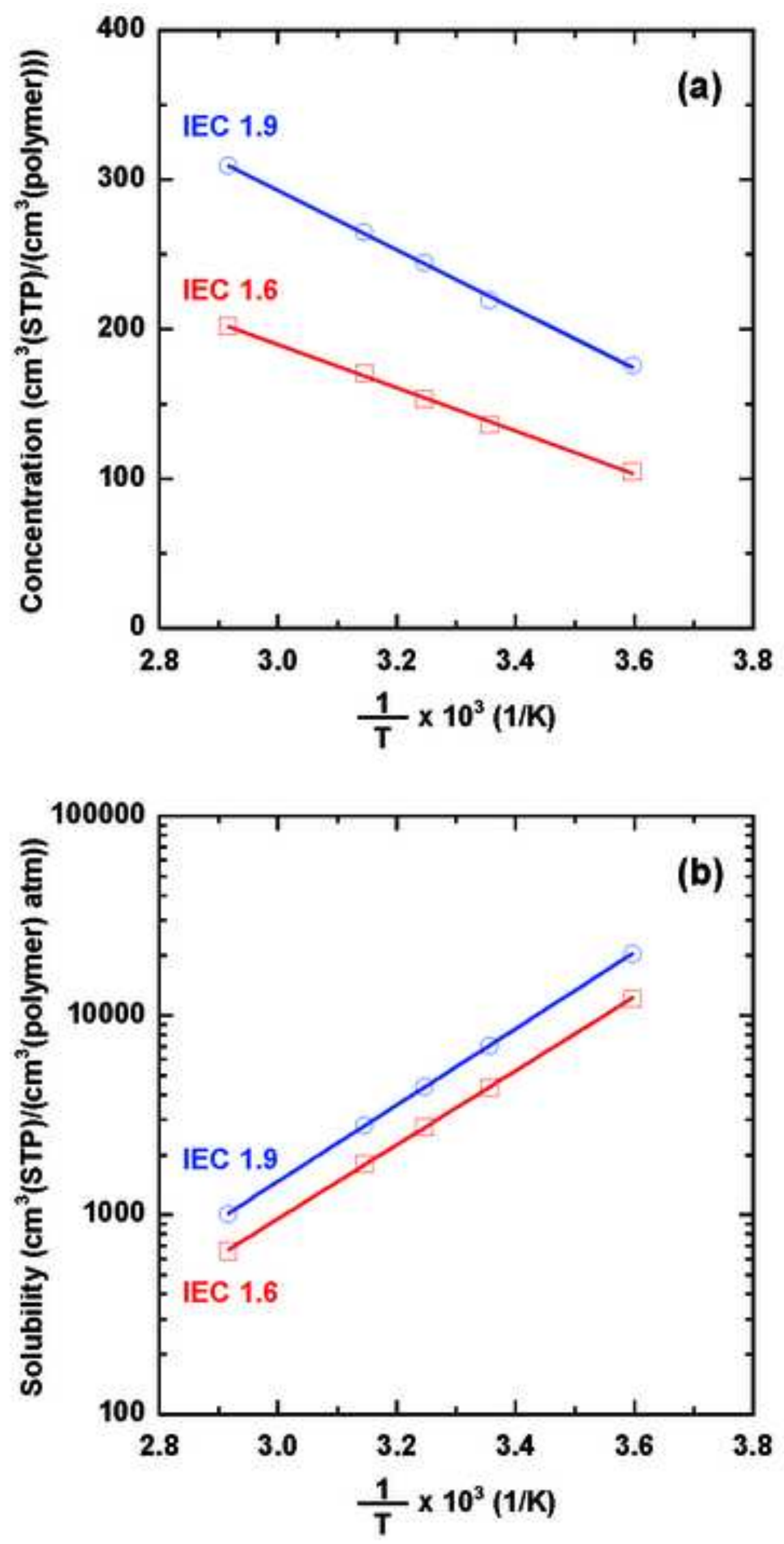
Figure 4

Click here to download high resolution image
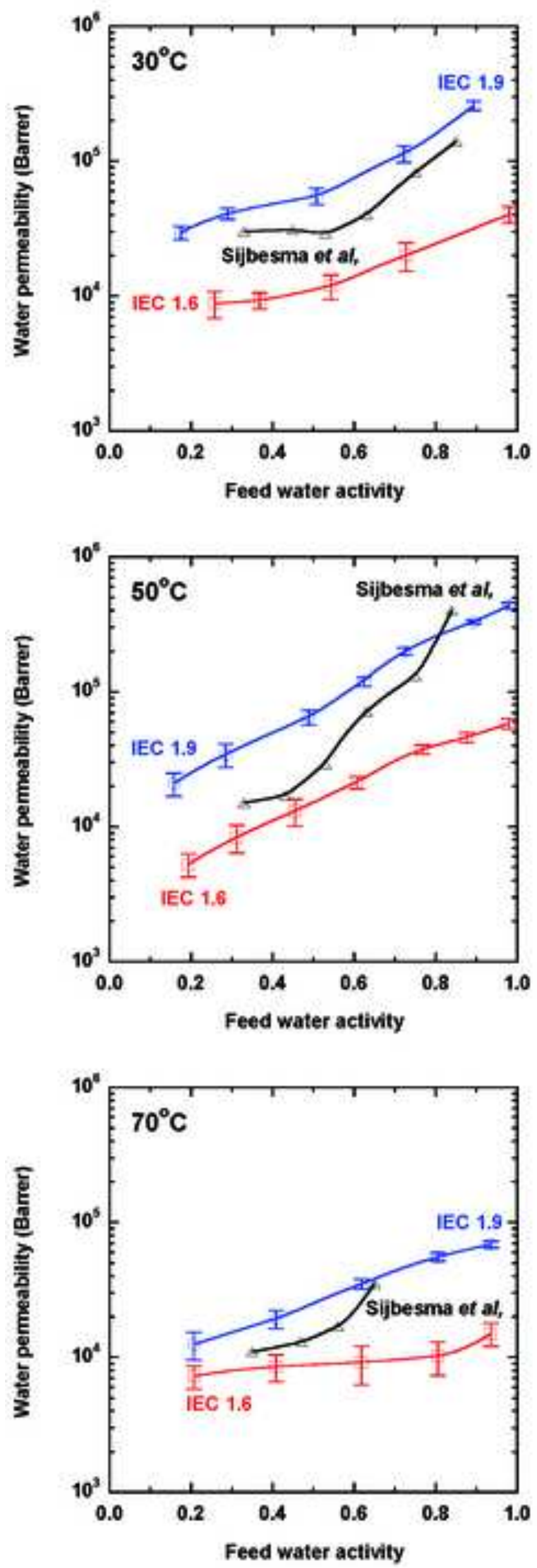


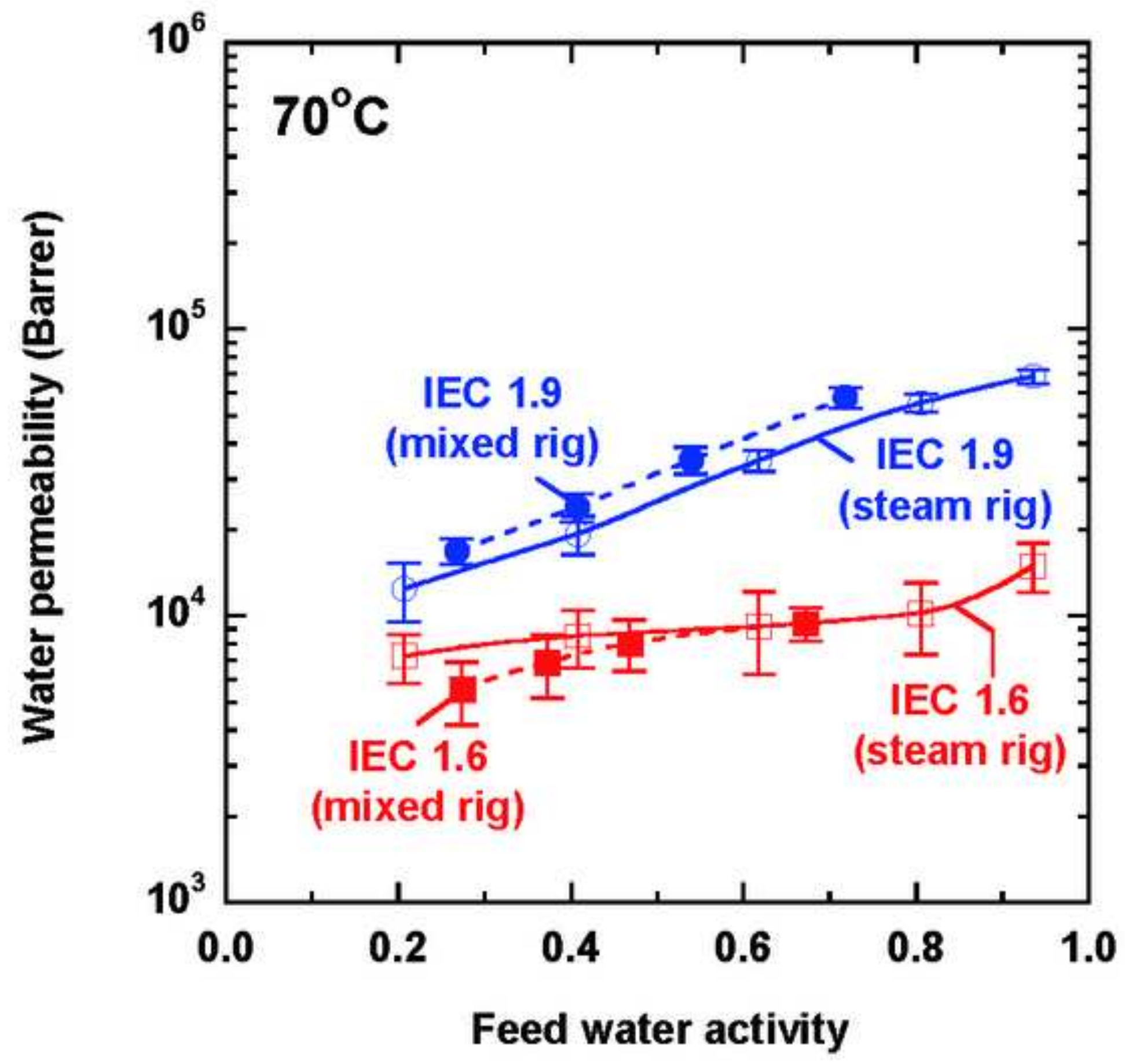




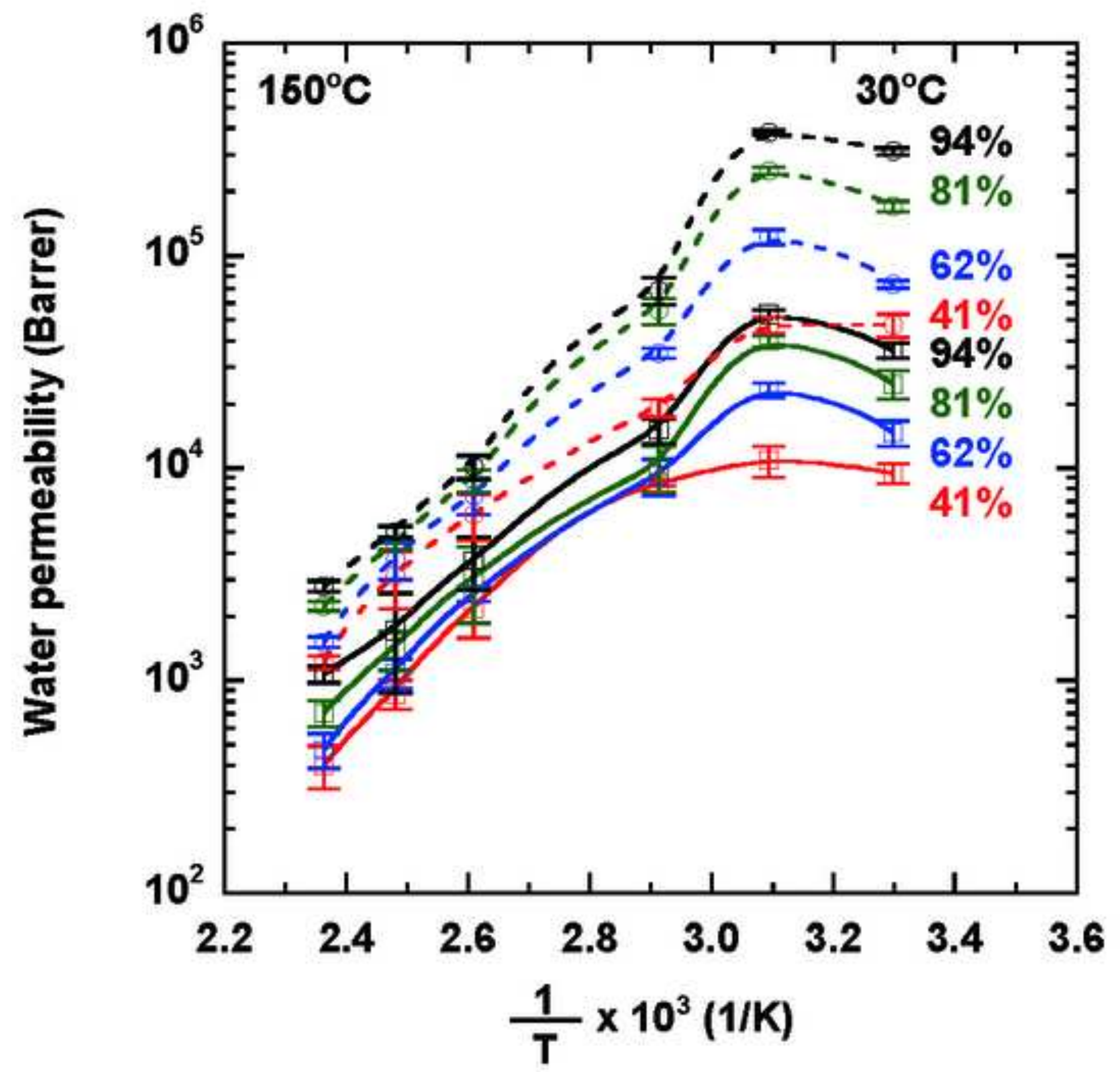


Figure 8

Click here to download high resolution image
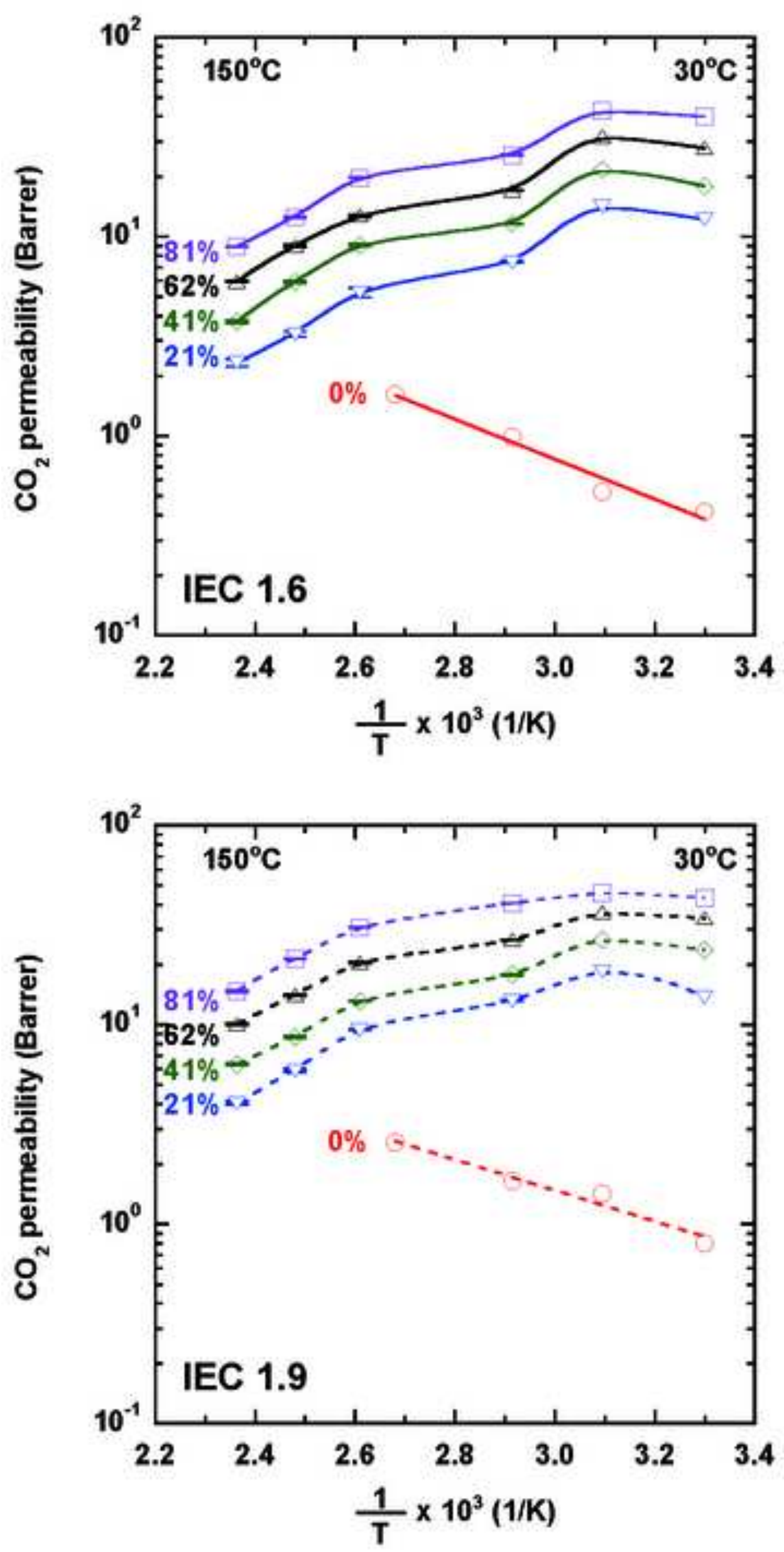
Figure 9

Click here to download high resolution image
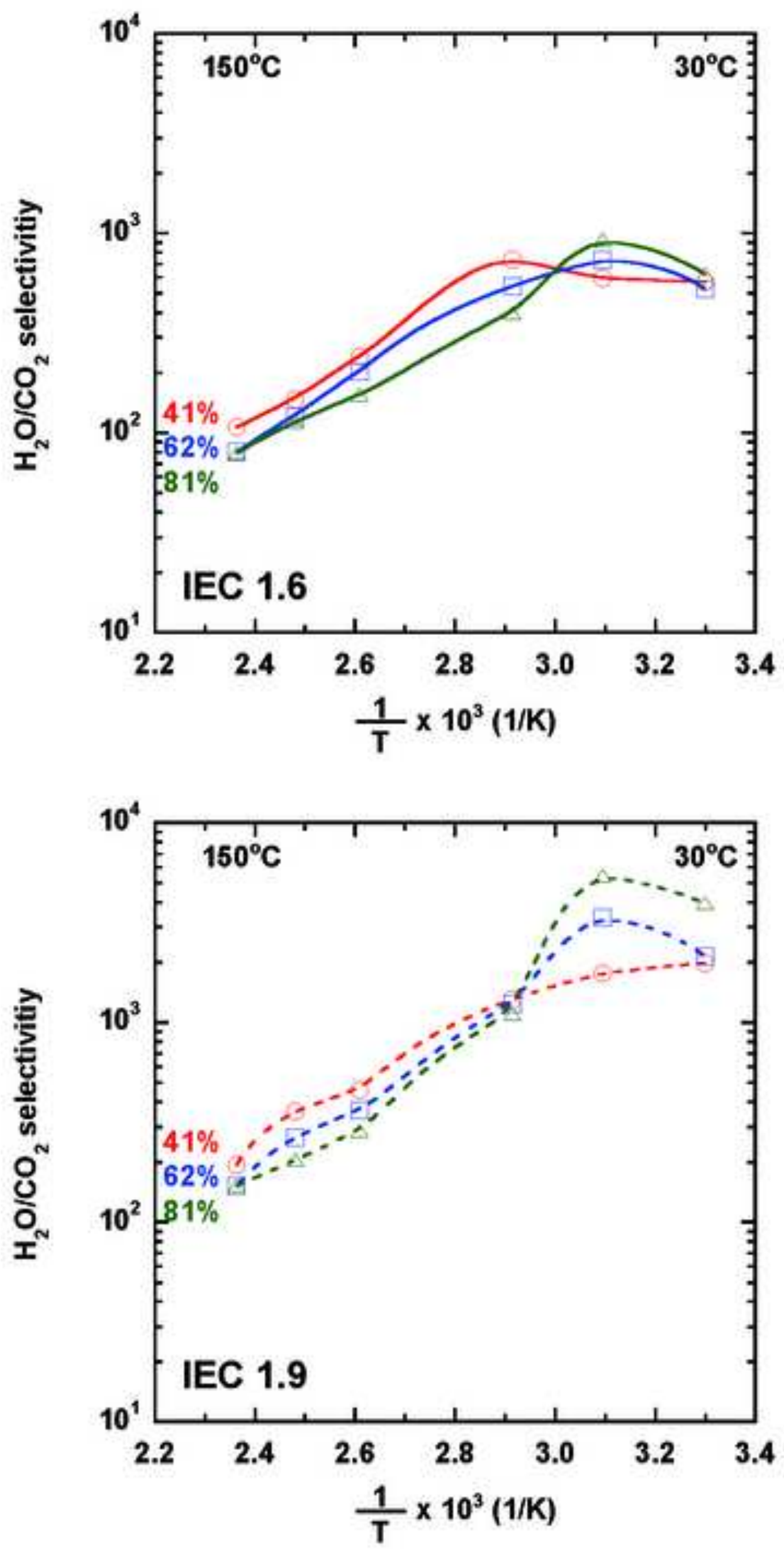


\section{University Library}

\section{- M M N E R VA A gateway to Melbourne's research publications}

Minerva Access is the Institutional Repository of The University of Melbourne

\section{Author/s:}

Azher, H;Scholes, C;Kanehashi, S;Stevens, G;Kentish, S

Title:

The effect of temperature on the permeation properties of Sulphonated Poly (Ether Ether) Ketone in wet flue gas streams

\section{Date:}

2016-12-01

\section{Citation:}

Azher, H., Scholes, C., Kanehashi, S., Stevens, G. \& Kentish, S. (2016). The effect of temperature on the permeation properties of Sulphonated Poly (Ether Ether) Ketone in wet flue gas streams. JOURNAL OF MEMBRANE SCIENCE, 519, pp.55-63. https:// doi.org/10.1016/j.memsci.2016.07.015.

Persistent Link:

http://hdl.handle.net/11343/123245 